\title{
Social Barriers to Nation Building in Afghanistan
}

\section{OPEN ACCESS}

Manuscript ID:

ASH-2021-09013887

Volume: 9

Issue: 1

Month: July

Year: 2021

P-ISSN: 2321-788X

E-ISSN: 2582-0397

Received: 05.04.2021

Accepted: 12.06.2021

Published: 01.07.2021

Citation:

Faqiri, Sayed Mohammad, and Abdul Shakoor

Faqirzada. "Social Barriers to Nation Building in Afghanistan." Shanlax International Journal of Arts, Science and Humanities, vol. 9, no. 1, 2021, pp. 19-25.

DOI:

https://doi.org/10.34293/ sijash.v9i1.3887

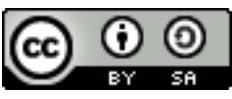

This work is licensed under a Creative Commons Attribution-ShareAlike 4.0 International License

\author{
Sayed Mohammad Faqiri \\ Teaching Assistant, Herat University, Afghanistan \\ https://orcid.org/0000-0003-4630-2699
}

\author{
Abdul Shakoor Faqirzada \\ Herat University, Afghanistan
}

\begin{abstract}
The present study aims to examine the social barriers to nation-building in Afghanistan. In this qualitative type of research, the semi-structured interview tools were used to collect data. After the interviews, the obtained information was coded and analyzed. The findings of this study showed that the most significant social barriers to the nation-building process in Afghanistan were the ethnic structure of power, wars, ethnic elites, and interference from neighboring countries, inability to use the presence of foreigners, traditional society, and the lack of cultural discourses, the definition of ethnic identity, hegemony, ethnic totalitarianism, and toxic antidote. Also, social factors on political, economic, cultural, and geographical issues were examined in this study. The most important political obstacles to the nation-building process in Afghanistan have been social disunity, the presence of foreigners, exceptional opportunity, political instability, and the lack of national political leaders and parties.

The most important cultural barriers are the illusion of conspiracy, cultural confrontation, and low level of awareness and lack of common aspirations. Recent findings of this study show that citizenship rights can be the central pillar in the establishment of a nation. Citizenship right is a new concept that equalizes the political, social, and cultural rights of all members in a society.
\end{abstract}

Keywords: Nation building, Afghanistan, Social barriers, Nation-state

\section{Problem Statement}

Although religion used to bridge the identity gap of the Afghan people as the safest refuge, today, and religious identity has found a new competitor, called nationalism. Currently, a significant number of Afghan people seek refuge in ethnicity instead of religion to fill the identity gap, which is why ethnic identities are put against each other and every event is interpreted ethnically. Another example of this can be seen in the fact that some of today's politicians who once had a jihadi background have taken refuge in ethnicity to stay in the country's politics and have reached an agreement with their ideological enemies.

Ethnicity is today the dominant discourse in the political culture of Afghanistan. Political conflicts in the country originate from the ethnic narratives. For example, a number of Pashtun elites have the ideal of a great Pashtunistan and a centralized government. A number of Tajik elites are divided into Khorasan-seeking and Federalist groups seeking a change in the country's political structure. A number of Hazara elites speak of Hazarastan, and another group calls for a federal system. At the same time, some Uzbek elites speak of Pan-Turkism and have a nostalgia authority of Turkish people. Although these demands have not been raised in the context of social movements, in some cases they are reflected in the media and other political circles. 
The emotional-identity symbols of ethnic groups in Afghanistan are different, each ethnic group has separate interpretations of the country's historical events, and none is willing to resort to dialogue and dialogue. Religion and nationalism should be defined as the main sources of identity building in the contemporary history of Afghanistan.

It seems that after 2002, security fields are being established on the central pillar of ethnicity rather than on the central pillar of religion. This issue reflects a profound change in the worldview of political groups. In the past, especially the time of Amanullah Khan, the government was threatened by the address of the religious-belief identity of the traditional society, or the non-institutional communist governments were threatened by such an address. However, nowadays, the opposition to the government is from the address of ethnic identities. The subject shows a structural change in the political sociology of Afghanistan.

Today, the identity crisis seems to be a serious threat in Afghan society. The examples of an identity crisis include ethnic divisions and differences over symbols, various interpretations of contemporary historical events, the structure of the system, the subject of digital identities. At the same time, the crisis of legitimacy has a longer life in the contemporary history of the country, and many governments have faced a crisis of legitimacy. On the other hand, turmoil and pressure should be considered as an important part of political events in the history of the country. The class conflict also shows us another face of the Afghan crisis environment, and this class conflict is increasing day by day.

Afghan ethnic nationalism has exceedingly grown and has emerged as a major obstacle to the discourse of national nationalism posed by the regime. Ethnic nationalism takes the coherence of phenomena as insiders and outsiders seriously and does not respect the national discourse of sovereignty. Therefore, the present study aims to identify and analyze the most important social barriers to the nation-building process in Afghanistan. This study also tries to acquire an understanding of the causes of social divides and explain political and cultural barriers to nation-building in Afghanistan.

\section{Research Significance}

The government in Afghanistan has not been able to achieve stability due to ethnic divisions. The Afghan government is highly fragile based on global indicators, and one of the factors that increase the importance of this research is the identification of social and cultural barriers to nation-building in this country. The biggest trap of political development in Afghanistan has been the inability of the government to win the trust of the various ethnic groups in the country, and therefore it is necessary to study this issue scientifically and identify the social barriers to nation-building.

\section{Research Objectives \\ Main Objective}

- Investigating the social barriers to nation building in Afghanistan.

\section{Minor Objectives}

- Investigating how social barriers to nationbuilding arise.

- Study of cultural barriers to nation building in Afghanistan.

- Investigating the role of government sovereignty and the geographical situation of the country in the process of nation-building in Afghanistan

\section{Research Questions \\ Main Objective}

- What are the social barriers to nation building in Afghanistan?

\section{Minor Objectives}

- How did these obstacles to the nation-building process arise in Afghanistan?

- What was the role of the government and uneven geography in the nation-building process in Afghanistan?

- How did cultural obstacles to the nation building process arise in Afghanistan?

\section{Necessity of the Study}

One of the causes of war in Afghanistan for all these years has been the lack of constructive interaction between government and society. The governments that came to power in Afghanistan were 
established in the cities and then overthrown within the villages. To date, no studies have been conducted to identify social barriers to nation-building in the country, and this issue needs to be further reflected in sociological research. The present study will be a good window for further research.

\section{Experimental Research Records}

Alireza Faraji Rad et al., has addressed the obstacles to nation-building in a qualitative study in 2011, entitled "Study of the Nation-Building Process in Afghanistan and the Obstacles Ahead". The findings of this study showed that "war, as a determinant of zeal in the minds of Afghans, institutionalized ethnicity instead of nation thinking and now Afghanistan should be considered a country made up of different tribes. Society in Afghanistan has always been stronger than the government. "That is why this pillar of the nation-state has never been able to play its special role in this traditional society. The process that took place in Iran and Turkey at the beginning of the twentieth century has never been successful in Afghanistan."

Sardar Nia Khel et al., conducted a study in 2012 entitled "Social Challenges of Modern State-Making in Afghanistan", in which an attempt was made to explain the obstacles and challenges of statebuilding in Afghanistan during the era of Hamid Karzai from the perspective of social gaps via the sociological explanation method. The findings of this study show that the most important challenges facing state-building in Afghanistan have been the severe and pervasive identity crisis, the clash of tradition and modernity, the crisis of legitimacy, the dominance of traditional and tribal culture over civic culture, cultural poverty, Extreme economic poverty, and traditional society

Maryam, Akbari in 2017 conducted research, entitled "Causal Conditions Affecting NationBuilding and its Roles in Afghanistan" using the fuzzy method in which she has addressed the obstacles to nation-building.

The findings of this study show that some of the main obstacles to nation building in Afghanistan include lliteracy, the existence of various discriminations, lack of appropriate religious propaganda, fragmentation of religious identities, dependence of groups on foreigners, incomplete and inefficient education, the rule of tribal cultures, the use of tools Religious beliefs in the direction of particular personal and group interests, heterogeneous beliefs, and ethnic tensions.

Seyyed Javad, Imam Jomehzadeh (2014), conducted research under the title of "Failed NationBuilding in Egypt" in a descriptive and explanatory method. After the fall of Hosni Mubarak, it was hoped that a new government would be established by the people, but the fall of Morsi and the return of the Supreme Military Council to power has obscured the state of the country. According to the results of this study, the nation-building will not occur in a country where different identities, each of which is imposed on their identities as claimed superior.

Mojtaba Ahmadian et al., conducted a study in 2013 entitled "Attitude-Measurement of Government-Nation Relationship in Iran" with the Q methodology. In this study, an attempt was made to model the mentality of individuals on how to improve the situation in the country. At the end of their research, they came up with four groups of people or four types of mindsets on how to improve the situation in the country. Thus, one of their demands was changing the government if the people are dissatisfied.

\section{Methodology}

The methodology of this research is qualitative as it employs the method of semi-structured interview and thematic analysis. Interview is used as a tool to collect information and create interaction between one person and several others. This interaction usually transpires between two people.

A semi-structured interview is an interview in which the interview questions are pre-defined and all respondents are asked the same questions, but they are free to answer in any way they want. The statistical population of the present study consists of educated and expert personalities in the fields of political science, sociology, economics and international studies.

The sample size in qualitative research is not known in advance. Sampling is conducted during the research until the occurrence of theoretical saturation. 


\section{Analysis of the Findings}

The interview data were analyzed after threestage coding (open, pivotal and selective) and information categorization.

\section{Reasons for not Forming a Nation}

Table 1: Reasons for not Forming a Nation in Afghanistan

\begin{tabular}{|c|l|c|}
\hline $\begin{array}{c}\text { Theme } \\
\text { reference } \\
\text { frequency }\end{array}$ & Extracted themes and contents & No \\
\hline 9 & $\begin{array}{l}\text { Ethnic construction of power } \\
\text { (ethnicity) }\end{array}$ & 1 \\
\hline 3 & Toxic antidote & 2 \\
\hline 2 & Ethnic elites & 3 \\
\hline 1 & Lack of a powerful government & 4 \\
\hline 6 & Illiteracy & 5 \\
\hline 3 & Lack of culture of tolerance & 6 \\
\hline 2 & $\begin{array}{l}\text { The gap between the government } \\
\text { and the nation }\end{array}$ & 7 \\
\hline 2 & The place of tension of great powers & 8 \\
\hline 2 & Ethnic identity & 9 \\
\hline 3 & $\begin{array}{l}\text { The traditional nature of society (the } \\
\text { rule of tribal culture) }\end{array}$ & 10 \\
\hline 4 & Fundamental barrier policy & 11 \\
\hline 2 & Ethnic diversity & 12 \\
\hline 3 & There was no will & 13 \\
\hline 2 & Lack of common values & 14 \\
\hline 1 & $\begin{array}{l}\text { Lack of clear definition of national } \\
\text { identity }\end{array}$ & 15 \\
\hline
\end{tabular}

As is clear in Table 1, the respondents consider these 15 cases as one of the most important reasons for the formation of the nation in Afghanistan. Here are the most important themes extracted.

\section{Ethnic Construction of Power}

According to the respondents, throughout history, power in Afghanistan has revolved around the ethnic pillar, and ethnicity has played a crucial role in the political, social, and cultural equations of Afghanistan since the formation of contemporary Afghanistan. One of the main obstacles to the formation of national identity in Afghanistan is the ethnic structure of power. According to the respondents, national identity will not be formed unless political power is detached from the colonization of ethnic groups.

\section{Toxic Antidote}

The term or concept of toxic antidote refers to the role of the media in Afghanistan. Media plays a key role as one of the factors of socialization and one of the influential powers in society, but since most of the Afghan media depend on the ethnic elite or a particular ethnic group, it has always acted in a negative direction. The media has always been used as a means of displaying ethnic power. Respondents believe that a cultural strategy should be developed in Afghanistan, on which the media can work for social solidarity.

\section{Ethnic Elites}

Ethnicity has been the best means of gaining power in Afghanistan, and ethnic elites have encouraged ethnic politics to gain power and remain in power. They have sought to ensure that Afghanistan never becomes a nation because the nationalization of Afghanistan has restricted their interests. Therefore, they have attempted to build a barrier to the nation-building process by fomenting ethnic, racial, linguistic, and regional issues.

\section{Lack of a Powerful Government}

Although this theme has been mentioned only once, a government needs the power to withstand the opposing and disruptive forces to be able to do all its special work in a practical society. Throughout Afghanistan's history, there have been fewer governments that have been able to carry out all their special tasks with authority and defeat the disruptive forces.

\section{Illiteracy}

Literacy is a basic requirement on which the pillars of development are based. Illiteracy and low level of public awareness have been one of the most influential reasons for the lack of a nation in Afghanistan. Respondents have also mentioned this theme six times, which shows its great impact.

\section{Lack of Culture of Tolerance}

Due to the inefficiency and incompatibility of governments, there has been mistrust between the government and the nation throughout history, so opportunists have used their personal advantage and 
caused mistrust between the government and the nation.

\section{Ethnic Diversity}

Some writers and scholars consider Afghanistan to be a museum of diverse ethnicities, but this diversity, due to war and instability, has never led to the establishment of a national government that is acceptable to all ethnic groups. Ethnic identities have caused conflicts due to low level of awareness in most cases under the influence of internal and external variables.

Respondents also considered ethnic incitement by politicians, ethnic diversity, lack of shared values, and incomprehensibility of national identity as other obstacles to nation-building in Afghanistan. Lack of tolerance in the country, as well as Afghanistan, becoming a battleground between the great powers is another issue that respondents believe has a negative impact on Afghanistan's transition to the establishment of national identity.

Table 2: Social Barriers to Nation Building

\begin{tabular}{|c|l|c|}
\hline No & Extracted themes and contents & $\begin{array}{c}\text { Theme } \\
\text { reference } \\
\text { frequency }\end{array}$ \\
\hline 1 & Class gap & 1 \\
\hline 9 & Ethnic structure of power & 2 \\
\hline 3 & the war & 3 \\
\hline 2 & Ethnic elites & 5 \\
\hline 3 & $\begin{array}{l}\text { Involvement of neighboring } \\
\text { countries }\end{array}$ & 6 \\
\hline 1 & $\begin{array}{l}\text { Inability to use the presence of } \\
\text { foreigners to their advantage }\end{array}$ & 7 \\
\hline 4 & The traditional nature of society & 8 \\
\hline 2 & Lack of discourse formation & 9 \\
\hline 2 & Ethnic definition of identity & 10 \\
\hline 1 & Seeking superiority and totality & 11 \\
\hline 1 & Lack of social solidarity & 12 \\
\hline 1 & Toxic antidote & 13 \\
\hline
\end{tabular}

Table 2 shows the 14 themes surrounding the social barriers to nation-building in Afghanistan, with the ethnic construction of power and war being the focus of most respondents.

\section{Ethnic Construction of Power}

Power in Afghanistan has always revolved around ethnicity, and the systems have been based on ethnicity. Power on the basis of ethnicity and not merit and ability can not only have serious consequences such as feelings of deprivation, strife, prejudice, supremacy, and greed but also incapacitate the government in society. Among the 16 respondents, no one considers the ethnic construction of power in Afghanistan as the main social obstacle to the nationbuilding process.

\section{War}

As verified by the respondents, the three respondents consider the interference of foreigners, especially neighboring countries, as one of the fundamental obstacles to the nation-building process in Afghanistan. They believe that countries with strategic goals in Afghanistan have always attempted to create ethnic, linguistic, and racial divisions in this country. Therefore, the intervention of foreign countries has been one of the main obstacles to the nation-building process in Afghanistan.

According to the respondents, in order to overcome the situation of mistrust, the dialogue between Afghan ethnic groups should be provided in order to get acquainted with each other. Also, class divisions should also be seriously taken into account as an important issue. Respondents also believe that superiority, lack of social solidarity, and traditional Afghan society are important barriers to the establishment of national identity. Of all the respondents who participated in this study, four respondents consider comprehensive traditionalism as one of the most fundamental and important obstacles to the nation-building process in Afghanistan. The findings of this study also show that Afghanistan in the past twenty years has not been able to take advantage of the presence of foreign forces to ensure political stability in the country, and today identity challenges still exist.

\section{Conclusion}

The findings of this study show that political stability is a basic necessity for development. Lack of political stability can lead to chaos and disorder. According to the respondents, Afghanistan is a 
country whose governments have always been changed by war and violence, not by the peaceful transfer of power. On the other hand, this situation is a clear sign of political instability. According to the respondents, Afghanistan is tribal land, and, to date, no powerful national political leader has emerged in the country, but all the leaders who have emerged in this country were ethnic leaders for whom only ethnic interests were concerned. Also, these ethnic leaders established political parties whose main central pillar was ethnicity. This situation has fragmented the country over several decades in a way that these parties launched ethnic wars to gain power, which prevented the establishment of the modern government.

Afghanistan's dependence on foreign aid, economic poverty, social disunity, cultural and religious conflict are other obstacles to nationbuilding in Afghanistan. Changing this situation will undoubtedly require long-term, medium-term, and short-term planning.

Since Afghanistan is a mountainous country, geography can be one of the basic and influential components in the nation-building process. However, the rugged geography of Afghanistan has been identified as a major obstacle to the nation-building. The findings of this study on the geographical barriers to nation-building in Afghanistan include lack of political, social and cultural participation, the long cultural distance between cities and villages, the formation of local powers, and the rural community's distrust of the central government.

Afghan society has suffered greatly from a lack of role models in the last century. The most important role models for Afghan society have been warriors, princes, warlords, princes, mujahideen, leftists, and the Taliban. For the past 18 years, role models in Afghanistan have been ethnic leaders, extremist mullahs, returnees from the West who have amassed enormous wealth through their positions. One of the most important factors of ethnicity in Afghan society is the role models who are themselves entangled with prejudice, discrimination, and ethnic and regional stereotypes. According to the findings of this study, the nation should be formed on the basis of citizenship rights. These rights include raising public awareness, strengthening the national spirit, creating culture tolerance, creating common values, and strengthening a sense of empathy through cultural discourses between different ethnic groups. To end the war it is necessary to achieve these basic citizenship rights.

\section{References}

Abdolaei, Ghavam, and Mehdi Malmir. "Presenting an Analytical Model to Investigate the NationState Gap." Political Science Research Journal, vol. 10, no. 1, 2014.

Ahmadi, Mohammad. Afghan Democracy Opportunities and Challenges. Afghanistan Institute for Strategic Studies Publication, 2014.

Ahmadian, Mojtaba and Ruhollah Eslami. AttitudeMeasurement of Government-Nation Relationship in Iran Q Methodology. 2013

Alam, Abdolrahman. Foundations of Political Science. Sepidar Publishing, 2013.

Alireza Mohseni, Tabrizi. "A Study of Social Trust with a Generational View of Society." Applied Sociology Publication, no. 22, 2011.

Ali Reza Samiei, Isfahani, and Amran Kiani. "Globalization and Nation-Building in PostConflict Countries Iraqi Research Sample." Quarterly Journal of Strategic Studies on Globalization, 2014.

Aminian, Bahador, and Sara Mashhadi. The Role of Myths in National Identity and NationBuilding Case: Iran. Shahid Bahonar University of Kerman, 2012.

Andishmand, Mohammad Ikram. The NationBuilding Government in Afghanistan. Saeed Publications, 2014.

Azad, Aliullah. Logic of Professional Research. ResalatShahr-e-Kitab Publishing, 2015.

Badakhshani. 18-19 Language and Identity Policy in the Heart of Asia. Armanshahr Publications, 2014.

Ebadi, Naghmeh, and Arian Gholipour. "Identifying the Factors Affecting Sassi Capital." Publishing the Modern Process and Developing, vol. 27, no. 2, 2014.

Farahmand, Mahnaz and Morteza Daman Bagh. "Cultural Duality and Social Distrust." Social Issues of Iran, no. 2, 2017. 
Faraji Rad, Alireza. A Study of the Nation-StateBuilding Process in Afghanistan and the Obstacles Ahead. Encyclopedia Publication, 2011.

Flick, Uwe. An Introduction to Qualitative Research. Ney Publishing, 2012.

Foroozeh, Ibrahim. Liberal Democracy and NationBuilding in Afghanistan. Quds Publications, 2015.

Ghavam, Abdolali, and Afshin Zargar. Understanding the Nation-State in International Relations Theories. Publication of Encyclopedia of Law and Politics, 2008.

Ghazaleh Taheri, Attar. "Designing to Explain the Model of Sustainable Nation-Building." Quarterly Journal of Strategic Research and Policy, 2014.

Hadian, Hamid. Weakness of the Nation-state Structure in Afghanistan: Geography and Ethnicity. 2009.

Haghshenas, Mohammad Javad, and Imran Yousefi. Opportunities and Threats of the NationBuilding Process in Afghanistan for Iran. 2007.

Havam, Seyed Abdolali. Understanding the NationState in International Relations. Publication of Encyclopedia of Law and Politics, 2008.

Imam Juma Zadeh, et al. "The Failed Nation-Nation in Egypt." Publication of the Quarterly Journal of Political and International Freedom, no. 5, 2014.
Janparvar, Mohsen. Convergence and Divergence in Afghanistan. 2010.

Ketabi, Mahmoud, and Vahid Ghasemi. Measuring Social Trust and Its Effective Factors in the Centers of Chaharmahal and Bakhtiari Cities. Publication of Applied Sociology, 2010.

Mahmoud Bahoush, Farduqi and Peyman Zanganeh. "A Study of Government - Nation-Building after the Cold War in Afghanistan with Emphasis on Three International, Regional and Domestic Dimensions." Sassit Quarterly, 2016.

Qureshi Crane, Seyed Hossein, and Aref Bijan. "The Role of the Islamic Republic of Iran in the Government-Nation Building Process in Afghanistan and Its Impact on Iran's National Security." Publication of the Political Science Quarterly, no. 13, 2017.

Ramyar, Seyed Javad. Intellectual Sociology in Afghanistan. Erfan Publishing, 2015.

Sardarnia, Khalilollah, and Hosseini Seyed Mehdi. "The Social Challenges of Modern StateBuilding in Afghanistan." World Politics, vol. 3, no. 3, 2014, pp. 37-63.

Seyed Emami, Kavous. Where does Ethnic Identity Come from? A Review of the Main Theory. 2008.

Vaezi, Hamzeh. Disturbed Identities Searching for Concepts and Foundations of the NationBuilding Process in Afghanistan. Badakhshan Publications, 2012.

\section{Author Details}

Sayed Mohammad Faqiri, Teaching Assistant, Herat University, Afghanistan

Abdul Shakoor Faqirzada, Herat University, Afghanistan 